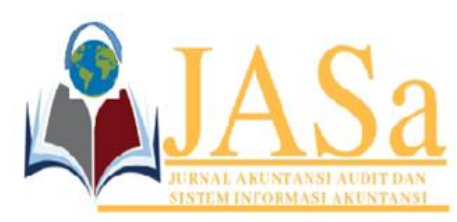

JASa (Jurnal Akuntansi, Audit dan Sistem Informasi Akuntansi)

Vol. 5 No.1/ April 2021

ISSN 2550-0732 print / ISSN 2655-8319 online

DOI;10.36555/jasa.v5i1.1532

\title{
THE EFFECT OF ACCOUNTING INFORMATION SYSTEMS AND INTERNAL CONTROL SYSTEMS ON THE QUALITY OF FINANCIAL STATEMENTS AT BPKAD
}

\author{
Kania*1, Abdul Hafiz Tanjung ${ }^{2}$ \\ Universitas National Pasim, Indonesia \\ kaniawungkul29@gmail.com
}

\begin{abstract}
The real effort to achieve transparency and accountability in the management of government finances, both central and regional governments, is by submitting accountability reports in the form of financial reports. The Bandung City Government is in charge of making financial reports, namely the Regional Financial and Asset Management Agency (BPKAD). The resulting government financial reports must be in accordance with the principles of being timely and prepared in accordance with Government Accounting Standards (SAP) in accordance with Government Regulation (PP) Number 71 of 2010. The Effect of Accounting Information Systems and Internal Control Systems on the Quality of Financial Statements at BPKAD Bandung The dependent variable in this study is the Quality of Financial Statements. This study uses a sample through the process of dividing the population into strata or what is called stratified random sampling. The data in this study are primary data obtained from distributing questionnaires directly to employees who are directly involved in making financial reports. The results of the study partially show the information system and internal control system have an effect on the quality of the report.
\end{abstract}

Keywords: Accounting Information Systems, Internal Control Systems, and Quality of Financial Statements

\section{INTRODUCTION}

The real effort to achieve transparency and accountability in the management of government finances, both central and regional governments, is by submitting accountability reports in the form of financial reports. The Bandung City Government is in charge of making financial reports, namely the Regional Financial and Asset Management Agency (BPKAD). The resulting government financial reports must be in accordance with the principles of being timely and prepared in accordance with Government Accounting Standards (SAP) in accordance with Government Regulation (PP) Number 71 of 2010.

The quality of financial reports is a summary of the results of financial reports that can provide financial information that can provide a better picture of the prospects and risks of an institution in accordance with established standards.

In accordance with PP. 71 of 2010 Qualitative Characteristics of financial statements are normative measures that need to be embodied in accounting information in order to fulfill its objectives. The characteristics of financial reports must be Relevant, Reliable, Comparable, and Understandable as a normative prerequisite so that government financial reports meet the desired quality and will be checked annually by the Supreme Audit Agency (BPK). 


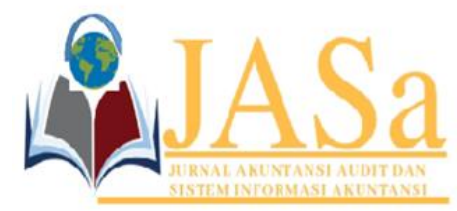

JASa (Jurnal Akuntansi, Audit dan Sistem Informasi Akuntansi)

Vol. 5 No.1/ April 2021

ISSN 2550-0732 print / ISSN 2655-8319 online

DOI;10.36555/jasa.v5i1.1532

One of the factors supporting the quality of financial reports is the internal control system. LKPD must be prepared based on an adequate internal control system and financial reports must be managed in accordance with SAP. The quality of LKPD is also determined by how good the internal control system is owned by local government agencies. Weak internal controls make it difficult to detect fraud / inaccuracies in the accounting process so that audit evidence obtained from accounting data becomes incompetent.

The effectiveness of the internal control system is needed to plan and report the results that will be evaluated by the internal control system committee. The function of the internal control system is used as an independent source of information about various organizational activities in order to assist objective and accountable decision making. Internal control components are in accordance with PP. 60 of 2008, namely the control environment, risk assessment, control activities, information and communication, and internal control monitoring.

The regional government that has the authority to supervise SPI is the district / city Inspectorate which is directly responsible to the Regent / Mayor. The Inspectorate is led by an Inspector who has a key role in assisting the Mayor in administering regional affairs and governance. As for carrying out these main tasks, supervisors have the function of planning a supervisory program, formulating policies and facilitating supervision, as well as examining, investigating, examining and evaluating supervisory tasks.

Another supporting factor for improving the quality of financial reports is the existence of an accounting information system, in which to produce good quality financial reports, a good system or procedure is needed to document all accounting transactions to be processed into financial reports.

Local governments are obliged to carry out SIA in government activities to meet the needs of public financial information. BPKAD Bandung has used the Accounting Information System since 2008 in an effort to solve problems that have arisen, but in fact in the last 5 (five) years since 2014, the results of the Bandung City audit report only received the first WTP in 2018. from BPK regarding regional management and asset.

Accounting Information Systems can be defined as a collection (integration) of sub-systems or components, both physical and non-physical, which are interconnected and harmoniously cooperate with each other to process transaction data related to financial issues into financial information (Azhar Susanto, 2017).

The Accounting Information System is an integrated activity that produces reports in the form of business transaction data that are processed and presented so that they become financial reports that have meaning for those who need them (Mardi, 2011).

Based on this definition, the authors conclude that the Accounting Information System is a system that implements an accounting process that aims to provide financial information to its users.

There are three objectives of the accounting information system according to (Mardi, 2011), namely: To fulfill every obligation in accordance with the authority given to someone (to fulfill obligations related to stewardship), Every information produced is valuable material. for management decision making (to support decision making by 


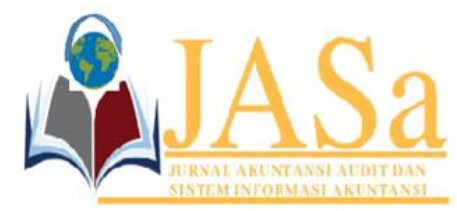

JASa (Jurnal Akuntansi, Audit dan Sistem Informasi Akuntansi)

Vol. 5 No.1/ April 2021

ISSN 2550-0732 print / ISSN 2655-8319 online

DOI;10.36555/jasa.v5i1.1532

internal decision makers). Information systems are needed to support the company's day-to-day operations (to support day-to-day operations).

The components of the accounting information system according to (Azhar Susanto, 2015), namely, Hardware, Software, Human (Brainware), Procedure (Procedure), Database, Communication Network (Communication Network).

The Internal Control System is an integral process for actions and activities carried out continuously by the leadership and all employees to provide adequate confidence in the achievement of organizational goals through effective and efficient activities, reliability of financial reporting, safeguarding state assets and compliance with laws and regulations. according to (Government Regulation No.60 of 2008).

The Internal Control System includes organizational structure, methods, and measures that are coordinated to maintain organizational assets, check the accuracy and reliability of accounting data, promote efficiency and encourage compliance with management policies (Mulyadi, 2016: 129).

From the above definition it can be concluded that the Internal Control System is a system designed to facilitate management in supervising the company, by placing employees who are in accordance with their fields and abilities in order to create reliable accounting data that can be accounted for.

Government Internal Control System, in government agencies there are 5 elements of an internal control system according to PP. 60 of 2008, which consists of: Environmental Control, Risk Assessment, Control Activities, Information and Communication, and Monitoring.

The objectives of the internal control system can be divided into two types (Mulyadi, 2016), namely: 1) Internal Control Accounting is part of the internal control system which includes organizational structure, methods and coordinated steps specifically to maintain organizational assets. and check accuracy. and reliability of accounting data. 2) Administrative Control, Includes organizational structure, methods and coordinated actions to promote efficiency and compliance with management policies.

Financial Report Quality are normative measures that need to be embodied in accounting information so that it can fulfill its objectives. 71 of 2010: 245.

Local governments must continue to make efforts to improve the quality of their financial reports. The financial reports presented by the local government are considered to be of quality if they meet the characteristics, namely relevant, reliable, comparable and understandable (Mahmudi, 2016: 11).

The quality of financial reports based on the conceptual framework of FSAB in the book (Herry, 2013) has defined the quality of financial reports by identifying several characteristics of the quality of financial reports, namely understandability, relevance, reliability, comparability and consistency.

Based on these definitions, the authors conclude that the quality of financial statements is a measure that shows that the financial statements presented are relevant, reliable, comparable and understandable.

The characteristics of financial reports according to (Abdul Hafiz Tanjung, 2011) are: Understandable, Relevant, and Comparable. 


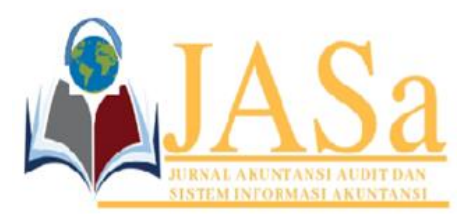

JASa (Jurnal Akuntansi, Audit dan Sistem Informasi Akuntansi)

Vol. 5 No.1/ April 2021

ISSN 2550-0732 print / ISSN 2655-8319 online

DOI;10.36555/jasa.v5i1.1532

\section{The Effect of Accounting Information Systems on the Quality of Financial Statements}

The application of the accounting information system has a positive and significant effect on the quality of financial reports. This is because the application of an accounting information system will simplify and accelerate the completion of tasks performed by each employee of the agency. meaning that a good information system helps in improving the quality of financial reports (Rukmi Juwita, 2013).

Every organization is required to always improve the quality of financial reports. This encourages companies to take advantage of accounting information systems in carrying out their daily tasks. The application of accounting information systems in organizations will facilitate and accelerate the completion of tasks by each individual. So one of the supporters of the quality of financial reports is the accounting information system, where financial reports are generated from a process based on good input, good process and good output. Thus, it is hoped that the resulting financial reports can meet the expected information and be able to improve the quality of results and the availability of timely financial reports (Zelda Triyani \& Chara Pratami T Tubarad, 2018).

H1: The Accounting Information System affects the quality of financial reports.

\section{Effect of Internal Control Systems on the Quality of Financial Statements}

One of the supporters of the quality of financial reports is the internal control system. LKPD must be prepared based on an adequate internal control system and financial reports are maintained in accordance with SAP. The high quality of LKPD is also determined by how good the internal control system is owned by local government agencies. Weak internal control makes it difficult to predict fraud / inaccuracies in the accounting process so that audit evidence obtained from accounting data becomes incompetent.

Internal control is an integral process of actions and activities carried out continuously by the leadership and all employees to provide adequate confidence in the achievement of organizational goals through effective and efficient activities, reliability of financial reporting, safeguarding state assets and compliance with laws and regulations. PP No. 60 of 2006).

H2: Internal Control System has an impact on the Quality of Financial Statements.

\section{METHODS}

Quantitative method is a research method based on a population or a specific sample, data collection using research instruments, quantitative or statistical data analysis, with the aim of testing the applied hypothesis. The method used in this research is a questionnaire method.

The operationalization of the variables needed to determine the types, indicators, and scale of the variables involved in this study are as follows: 1) Independent variables are variables that are considered to influence other variables that cause changes or the emergence of the dependent variable. . ), so in this study there are two independent variables studied, namely, the Accounting Information System and the Internal Control System. 2) the dependent variable, the dependent variable, is a variable that responds to changes in other variables (Bambang Soedibjo 


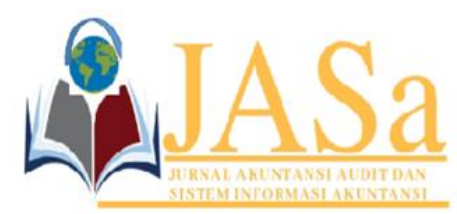

JASa (Jurnal Akuntansi, Audit dan Sistem Informasi Akuntansi)

Vol. 5 No.1/ April 2021

ISSN 2550-0732 print / ISSN 2655-8319 online

DOI;10.36555/jasa.v5i1.1532

2017). So in this study the dependent variable is the quality of the financial statements. Variable operations are needed to describe research variables in the concept of dimensions and indicators.

\section{Sources and Methods of Collecting Data}

Primary data is information obtained for the first time by researchers regarding the variables which are the main objectives of the study. Primary data is specifically collected by researchers to answer research questions. Primary data can be in the form of subject opinion individually or in groups. Primary data can be obtained by giving questionnaires directly to 52 employees who are directly involved in making financial reports at BPKAD Bandung, the type of questions used are closed. "Likert scale 'is used to measure attitudes and behavior in organizational or management research (Bambang. Soedibjo 2017). Statements on the Likert scale can be in the form of positive or negative statements. In this study the authors used positive and negative statements, the scores for positive and negative statements can be seen in table 1 as follows:

Table 1. Questionnaire scores for positive and negative statements

\begin{tabular}{ccc}
\hline \multicolumn{3}{c}{ Questionnaire scores for positive and negative statements } \\
\hline Strongly agree & Scores Positive & Scores Negative \\
Agree & 5 & 1 \\
Neutral & 4 & 2 \\
Disagree & 3 & 3 \\
Totally disagree & 2 & 4 \\
\hline
\end{tabular}

Source:Bambang S. Soedibjo 2017: 70

\section{Data collection technique}

Population is a collection of subjects or measurements of the problem to be studied (Bambang S. Soedibjo 2017). The population in this study were all employees who were directly involved in making financial reports at BPKAD Bandung, totaling 109 people from 5 divisions.

Sample

The sample is part of the population. The sample contains subjects or members selected from the population (Bambang S. Soedibjo 2017). The sampling technique used is Stratified Random Sampling, which is a sampling technique with attention to a level (strata) in the population elements of 52 people. The technique of determining the sample size uses the Yamane formula (1967).

\section{Data analysis method}

Data analysis is an important step in completing a research project (Bambang S. Soedibjo 2017). The data is an accurate description of the variables and functions as a means of proving a hypothesis. Therefore, whether the data is correct or not will determine the quality of a research result. On the other hand, whether the questionnaire or questionnaire instrument is correct or not must be used to obtain valid and reliable data about the variables being measured. 


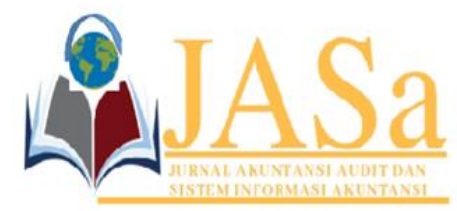

JASa (Jurnal Akuntansi, Audit dan Sistem Informasi Akuntansi)

Vol. 5 No.1/ April 2021

ISSN 2550-0732 print / ISSN 2655-8319 online

DOI; $10.36555 /$ jasa.v5i1.1532

\section{Descriptive Analysis}

By using the research method, a significant relationship will be known between the variables studied so that the conclusions will clarify the picture regarding the object under study. According to (Bambang S. Soedibjo 2017) what is meant by descriptive statistical analysis is that it contains calculations to see how the patterns or characteristics of the data are and detect the irregularities of the response in answering the questionnaire. This descriptive approach is used to clarify or describe the facts that occur in the variables studied, namely the accounting information system, internal control system, and the quality of financial reports. To know the description of each variable, the average formula is used. This average value is obtained by adding and totaling in each variable, then divided into the number of respondents.

\section{Associative Analysis}

Association is a form of phenomenon that shows a relationship between two or more variables. However, the existence of a relationship or association between two variables does not mean that there is a cause and effect relationship in it. The existence of an association is not sufficient as a consideration to state that one variable causes another variable to occur. However, researchers must observe the association between these variables, for this reason a study is conducted.

\section{Validity test}

Conventionally, the term validity can be interpreted as an empirical measure that reflects the true meaning of the concept being studied (Bambang S. Soedibjo 2017). The validity test in this study was conducted using construct validity. Construct validity discusses the content and meaning of a concept as well as the measuring tools used to measure the concept. In this study, the validity test was conducted using Partial Least Square (PLS) by testing the convergent and discriminant validity. Convergent Validity, assessed based on the loading value calculated by PLS. The measurement scale for the loading value is 0.7 , but the value from 0.5 to 0.6 is considered sufficient and its validity is accepted (Gendro Wiyono, 2011). Discriminant Validity, is assessed by two methods, namely the method of comparing the square roots of AVE with latent vertical correlation, and the cross loading method states that all itemhaus is greater than other constructs.

\section{Reliability Test}

Reliability test is used to determine whether the indicators of all research variables used are good constructs or not in forming a latent variable. There are two kinds of reliability tests presented, namely composite reliability and Cronbach's alpha. A variable is said to be realistic if it provides a Cronbach's alpha value> 0.7 .

\section{Measurement of Model Structure}

In this study, the authors examined the structure of the model by measuring the Coefficient of Determination $\left(R^{2}\right)$ and Path Coefficient techniques (Hair Jr. et. Al., 2017). Coefficient of Determination $\left(R^{2}\right)$, the $R$-square value is used to measure the degree of variation in changes in the independent variable on the dependent variable. The higher the $\mathrm{R}^{2}$ value, the better the prediction model of the proposed model. The value on $R^{2}$ can be used as a measure of the influence of the independent variable on the dependent variable. A value of $R^{2}>0.1$ is acceptable. Path Coefficient $(\beta)$ is the value of the path coefficient or the magnitude of the latent construct relationship / influence. This test is carried out using the bootsraping procedure by looking at the 


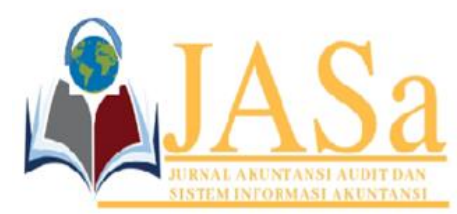

JASa (Jurnal Akuntansi, Audit dan Sistem Informasi Akuntansi)

Vol. 5 No.1/ April 2021

ISSN 2550-0732 print / ISSN 2655-8319 online

DOI;10.36555/jasa.v5i1.1532

value of the parameter coefficient and the significant value of the t-statistic. This test is carried out to ensure that the relationship between constructs is strong. It can be said that between constructs has a strong relationship if the path coefficient value is more than 0.1 . And the relationship between latent variables is said to be significant if the path coefficient is at the level of 0.1 .

\section{Hypothesis test}

Tests were carried out using a bootstrapping procedure using PLS analysis. Then to see the significance measure of the support of the hypothesis using a comparison of t-table values with t-statistics. If the statistical values are higher than the $\mathrm{t}$-table value, the hypothesis is supported. For probability values, the $\mathrm{p}$-value with $\alpha=$ $10 \%$ is less than 0.1 . The t-table value for $\alpha$ is 1.298 (Hussein, 2015).

Furthermore, simultaneous hypothesis testing ( $F$ test) was carried out with a confidence level of $10 \%$. If the calculated $F$ value is greater than the $F$ table, the coefficient of determination is significant and the null hypothesis $(\mathrm{Ho})$ is rejected (Sugiyono, 2016).

\section{Descriptive Analysis of Data \\ Outer Model Test}

RESULTS AND DISCUSSION

The measurement model test is carried out to ensure that the measurement model used is valid and reliable. The validity of the measurement model used is evaluated by convergent validity and discriminant validity for the indicator. Convergent validity is assessed based on the outer loading value which shows the correlation between the item score and the construct score. In this study the value of outer loading $\alpha>0.1$ is considered good and suitable for use in research. The following is an image of outer loading:

Table 5 The Results Of Outer Loading Of Accounting Information System Variables

\begin{tabular}{cccc}
\hline Variable & Code & $\begin{array}{c}\text { Outer Loading/ Loading } \\
\text { Factor (LF) }\end{array}$ & Infomation \\
\hline & X1.01 & 0,957 & Valid \\
& X1.02 & 0,811 & Valid \\
X1.03 & 0,762 & Valid \\
& X1.04 & 0,741 & Valid \\
& X1.05 & 0,838 & Valid \\
AIS & X1.06 & 0,850 & Valid \\
& X1.07 & 0,846 & Valid \\
& X1.08 & 0,851 & Valid \\
& X1.09 & 0,792 & Valid \\
& X1.10 & 0,738 & Valid \\
& X1.11 & 0,776 & Valid \\
& X1.12 & 0,722 & Valid \\
\hline
\end{tabular}

Source: Output PLS, Processed Data 2020 


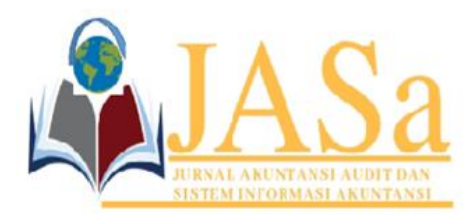

JASa (Jurnal Akuntansi, Audit dan Sistem Informasi Akuntansi)

Vol. 5 No.1/ April 2021

ISSN 2550-0732 print / ISSN 2655-8319 online

DOI; $10.36555 / j a s a . v 5 i 1.1532$

Dilihat dari tabel 5 bahwa hasil dari system informasi akuntansi sudah menenjukan hasil yang valid dan di atas 0,5 outer loading bernilai rata-rata 0,787 dan menghasilkan keterangan valid dan dapat diolah Kembali

Table 6 The Results Of Outer Loading Of The Internal Control System Variables

\begin{tabular}{cccc}
\hline Variable & Code & $\begin{array}{c}\text { Outer Loading/ } \\
\text { Loading Factor (LF) }\end{array}$ & Infomation \\
\hline & X2.01 & 0,835 & Valid \\
& X2.02 & 0,788 & Valid \\
& X2.03 & 0,76 & Valid \\
ICS & X2.04 & 0,859 & Valid \\
& X2.05 & 0,853 & Valid \\
& X2.06 & 0,958 & Valid \\
& X2.07 & 0,732 & Valid \\
& X2.08 & 0,814 & Valid \\
& X2.09 & 0,878 & Valid \\
& X2.10 & 0,912 & Valid \\
\hline
\end{tabular}

Source: Output PLS, Processed Data 2020

Dilihat dari tabel 6 bahwa hasil dari sistem pengendalian internal sudah menenjukan hasil yang valid dan di atas 0,5 outer loading bernilai rata-rata 0,887 dan menghasilkan keterangan valid dan dapat diolah Kembali.

Tabel 7 The Results Of Outer Loading Of The Quality Of Financial Reports

\begin{tabular}{cccc}
\hline Variable & & & \\
& Code & Outer Loading/ Loading Factor (LF) & Infomation \\
& & & \\
\hline Y.01 & 0,877 & Valid \\
KLK & Y.02 & 0,878 & Valid \\
& Y.04 & 0,968 & Valid \\
& Y.05 & 0,816 & Valid \\
& Y.06 & 0,831 & Valid \\
& Y.07 & 0,740 & Valid \\
Y.08 & 0,864 & Valid \\
\hline
\end{tabular}

Source: Output PLS, Processed Data 2020

Discriminant validity is assessed by looking at cross loading, that is, if the construct correlation with the measurement item is greater than the other constructs, then it shows that latent constructs predict the size of their block better than the size of the other blocks. 


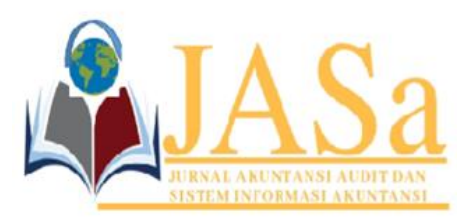

JASa (Jurnal Akuntansi, Audit dan Sistem Informasi Akuntansi)

Vol. 5 No.1/ April 2021

ISSN 2550-0732 print / ISSN 2655-8319 online

DOI;10.36555/jasa.v5i1.1532

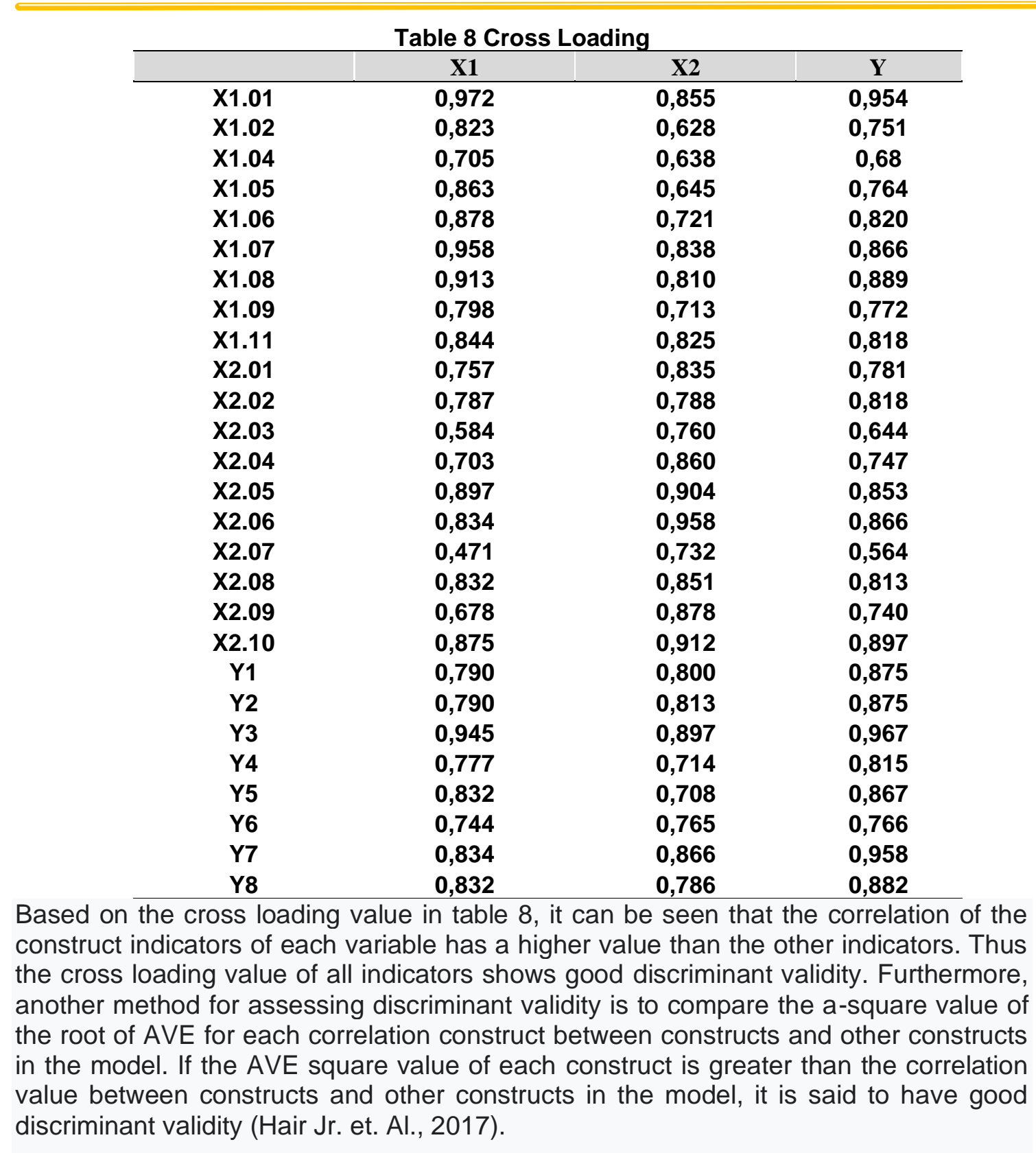

Table 9 Fornell Lacker

\begin{tabular}{cccc}
\hline & X1 & X2 & Y \\
\hline X1 & $\mathbf{0 , 9 4 6}$ & & \\
X2 & 0,656 & $\mathbf{0 , 9 1 4}$ & $\mathbf{0 , 9 1 1}$ \\
$\mathbf{Y}$ & 0,817 & 0,787 & \\
\hline & \multicolumn{2}{c}{ Source: Output PLS, Processed Data 2020 }
\end{tabular}

Submitted: January 14, 2021; Accepted: Marchr 06, 2021;

Published: April 24, 2021; Website: http://journalfeb.unla.ac.id/index.php/jasa 


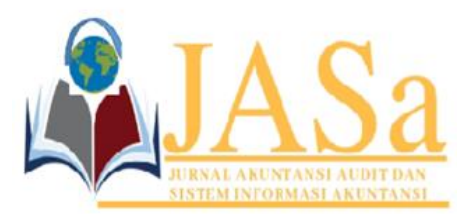

JASa (Jurnal Akuntansi, Audit dan Sistem Informasi Akuntansi)

Vol. 5 No.1/ April 2021

ISSN 2550-0732 print / ISSN 2655-8319 online

DOI;10.36555/jasa.v5i1.1532

The table above shows that the AVE root of each construct has a higher value than the other constructs. So that this construct has a higher value than other constructs. So that this construct has a good discriminant validity value.

Besides the validity test, the reliability test was also carried out. Reliability is measured by two criteria, namely composite reliability and Cronbach's alpha. The construct is said to be reliable if both values are $>0.7$.

Table 10 Cronbach's Alpha and Composite Reliability

\begin{tabular}{ccc}
\hline Variabel & $\begin{array}{c}\text { Cronbach's } \\
\text { Alpha }\end{array}$ & $\begin{array}{c}\text { Composit } \\
\text { Reliability }\end{array}$ \\
\hline X1 & 0,950 & 0,958 \\
X2 & 0,954 & 0,960 \\
Y & 0,948 & 0,957 \\
\hline \multicolumn{2}{l}{ Source: Output PLS, Processed Data 2020 }
\end{tabular}

Cronbach's Alpha measures the lower limit of the reliability value of a construct, while composite reliability measures the real value of the reliability of a construct Inner Model Test

The inner model test is done by measuring the coefficient of determinant $\left(R^{2}\right)$ and the Path Coefficient $(\beta)$ for the independent variables then assessing the significance based on the t-statistic for each path. The structural model of this research can be seen in the following table:

Table 11 Score Coefficient determinant $\left(\mathrm{R}^{2}\right)$

\begin{tabular}{lc}
\hline & R-Square \\
\hline Quality of Financial Reports & 0,957
\end{tabular}

Source: Output PLS, Processed Data 2020

In the table above, it can be seen that the value $\left(R^{2}\right)$ of the SIA and SPI variables to the KLK variable is 0.957 . This means that the variable rate of change in the SIA and SPI variables on the KLK variable is $95.7 \%$, while $4.3 \%$ is explained by other variables outside the one under study.

Then, to see the significance of the influence between variables, it can be done by looking at the path corfficient and the t-statistical significance value in the following table. The construct is said to have a strong relationship if the path coefficient valueis $>0$

Table 12 Path Coefficients (Mean, STDEV, T-Values)

\begin{tabular}{ccccccc}
\hline & $\begin{array}{c}\text { Original } \\
\text { Sampel }\end{array}$ & $\begin{array}{c}\text { Sampel } \\
\text { Mean }\end{array}$ & $\begin{array}{c}\text { Standard } \\
\text { Deviation }\end{array}$ & $\begin{array}{c}\mathbf{T} \\
\text { Statistics }\end{array}$ & $\begin{array}{c}\mathbf{P} \\
\text { Values }\end{array}$ & $\begin{array}{c}\text { The } \\
\text { Result }\end{array}$ \\
\hline X1->Y & 0,608 & 0,627 & 0,173 & 3,511 & 0,000 & $\begin{array}{c}\text { Beceted } \\
\text { Be }\end{array}$ \\
X2->Y & 0,395 & 0,375 & 0,174 & 2,277 & 0,0023 & Acceted \\
\hline \multicolumn{7}{c}{ Source: Output PLS, Processed Data 2020} \\
\end{tabular}




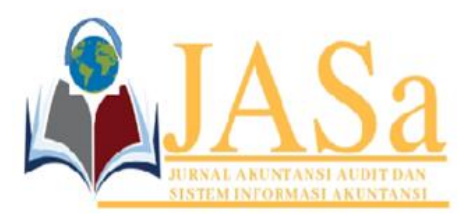

JASa (Jurnal Akuntansi, Audit dan Sistem Informasi Akuntansi)

Vol. 5 No.1/ April 2021

ISSN 2550-0732 print / ISSN 2655-8319 online

DOI;10.36555/jasa.v5i1.1532

Based on the table above, it explains the relationship between variables as follows The path coefficient from SIA to KLK is 0.608 and it can be said that the construct has a strong relationship. The path coefficient from SPI to KLK is 0.395 and it can be said that the construct has a strong relationship.

\section{Hypothesis testing}

This test is performed using a bootsrapping procedure using PLS analysis. Then to see the significance size of the support of the hypothesis using a comparison of t-table and t-statistics. If the t-statistic value is higher than the t-table value, then the hypothesis is supported. For probability values, the $p$-value with $\alpha=10 \%$ is less than 0.1 . The t-table value for $\alpha=10 \%$ is 1.298 .

\section{Hypothesis Test Results 1}

The first hypothesis to be tested is that the accounting information system has a positive effect on the quality of financial reports at BPKAD Bandung, so based on table 12 above, it can be seen that the direct effect of accounting information systems on the quality of financial reports has a statistical value of 3.511>1.298 and a p-value of $0.000<0,1$ which indicates that this influence is significant, and the path coefficient value is 0.608 which indicates that the accounting information system variable has a positive effect on the quality of financial reports at BPKAD Kota Bandung so that it means that the first hypothesis is accepted.

\section{Hypothesis II Test Results}

The second hypothesis testing is that the internal control system has a positive effect on the quality of financial reports at BPKAD Bandung City has a tstatistic of $2.277>1.298$ and a p-value of $0.023<0.1$, which indicates that the effect is significant, and the path coefficient value of 0.395 indicates that the system variable Internal control has a positive and significant effect on the quality of financial reports at BPKAD Bandung City so it means that the second hypothesis is accepted.

\section{F Test Results}

To determine whether or not the accounting information system and the internal control system are significant for the quality of financial statements, it is tested using the $F$ test. Where the F count has a value of $545.267>F$ table 2.41 , it can be concluded that $\mathrm{Ho}$ is rejected. $\mathrm{Ha}$ is accepted. Thus the accounting information system and the internal control system simultaneously play a role in improving the quality of financial reports. 


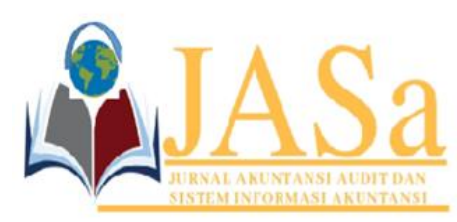

JASa (Jurnal Akuntansi, Audit dan Sistem Informasi Akuntansi)

Vol. 5 No.1/ April 2021

ISSN 2550-0732 print / ISSN 2655-8319 online

DOI;10.36555/jasa.v5i1.1532

Table 13 Summary of the results of the hypothesis

\begin{tabular}{|c|c|c|}
\hline Hypothesis & Description & Result \\
\hline 1 & $\begin{array}{l}\text { The variable path coefficient of SIA to } \\
\text { KLK is } 0.608 \text { with a } t \text {-statistic value of } \\
3.511>t \text { table of } 1.298 \text {. }\end{array}$ & Accepted \\
\hline 2 & $\begin{array}{c}\text { The path coefficient of the SPI variable } \\
\text { to KLK is } 0.395 \text { with a t-statistic value } \\
\text { of } 2.277>t \text { table } 1.298 \text {. }\end{array}$ & Accepted \\
\hline 3 & $\begin{array}{l}\text { Based on the results of } R^{2} \text { of } 0.957, \text { it } \\
\text { means that SIA and SPI have an effect } \\
\text { on KLK simultaneously }(95.7 \%) \text {. This is } \\
\text { supported by the results of } F \text { count } \\
\text { valued at } 545.267>\text { from } F \text { table } 2.41 .\end{array}$ & Accepted \\
\hline
\end{tabular}

Source: Primary data that is processed, 2020

\section{CONCLUSIONS}

This study examines the effect of accounting information systems and internal control systems on the quality of financial reports at BPKAD Bandung City. In this study, the object of research is employees who are directly involved in the making of financial reports. Respondents in this study amounted to 52 people. The method used in analyzing this research data is to use the Structural Equation Model (SEM) with the Partial Least Square (PLS) approach. The conclusions from the results of this study are as follows:The accounting information system has a significant positive effect on the quality of financial reports at BPKAD Bandung City. The accounting information system is a set of computer-based systems designed to collect, process, record and process data transactions so as to produce information that is presented to internal and external parties. One of the factors supporting the quality of financial reports is the accounting information system, where financial reports are generated from a process based on good input, good process, and good output. The internal control system has a significant positive effect on the quality of financial reports at BPKAD Bandung City. The government SPI is expected to achieve organizational goals through an integral process of actions and activities by the leadership and all employees continuously to provide adequate confidence that is carried out through effective and efficient activities. 


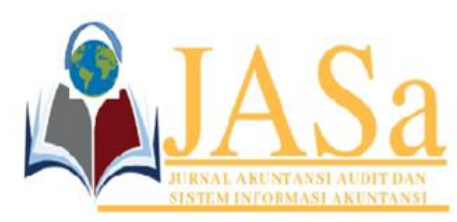

JASa (Jurnal Akuntansi, Audit dan Sistem Informasi Akuntansi)

Vol. 5 No.1/ April 2021

ISSN 2550-0732 print / ISSN 2655-8319 online

DOI;10.36555/jasa.v5i1.1532

So the better the SPI is in implementing the control environment, risk assessment, control activities, information and communication, and monitoring, the better the quality of financial reports will be.

\section{REFERENCES}

Abdul Hafiz Tanjung (2011). Pengantar Akuntansi. Bandung: Universitas Nasional Pasim.

Azhar Susanto (2017). Sistem Informasi Akuntansi. Bandung: Lingga Jaya.

Bambang S. Soedibjo (2017). Pengantar Metode Penelitian. Bandung: Universitas Nasional Pasim Bandung.

Gendro,Wiyono. 2011. Merancang Penelitian Bisnis dengan Alat Analisis SPSS 17.0 \& Smart PLS 2.0. Yogyakarta: Percetakan STIM YKPM.

Hair Jr., J. F., Hult, G. T. M., Ringle, C. M., dan Sarstedt, M. 2017. A Primer On Partial Least Squares Structural Equation Modeling (PLS-SEM) $2^{\text {nd }}$ Edition. Los Angeles : SAGE Publication Inc.

Herry (2013). Teori Akuntansi. Jakarta: Fakultas Ekonomi Universitas Indonesia.

Hussein, A. S. 2015. Modul Ajar Penelitian Bisnis dan Manajemen Menggunakan Partial Least Square (PLS) dengan SmartPLS 3.0. Malang : Universitas Brawijaya.

Mahmudi (2016). Analisis Laporan Keuangan Pemerintah. Yogyakarta: UPP STIM YKPN.

Mardi (2011). Sistem Informasi Akuntansi. Bogor: Ghalia Indonesia.

Mulyadi (2016). Sistem Akuntansi Edisi 4. Jakarta: Salemba Empat.

Peraturan Pemerintah No. 71 Tahun (2010). Standar Akuntansi Pemerintahan. Indonesia: Republik Indonesia.

Peraturan Pemerintah No. 60 Tahun (2008). Sistem Pengendalian Internal.

Rukmi Juwita (2013). Pengaruh Implementasi Standar Akuntansi Pemerintah dan Sistem Informasi Akuntansi terhdap Kualitas Laporan Keuangan. Trikonomika, 201-214.

Sugiyono. 2016. Metode Penelitian Manajemen. Bandung : Alfabeta.

Zelda Triyani \& Chara Pratami T Tubarad (2018). Pengaruh Sistem Informasi Akuntansi dan Sistem Pengendalian Internal terhadap Kualitas Laporan Keuangan Daerah. Jurnal Akuntansi dan Keuangan, 1-31. 